\title{
Salinity management for irrigation with saline-sodic wastewater under corn cultivation
}

\author{
Farzam Moghbel ${ }^{* 1}$, Behrouz Mostafazadeh-Fard ${ }^{2}$, Seyed Ali Mohammad Mirmohammady Maibody ${ }^{3}$ and \\ Esmaeil Landi ${ }^{2}$ \\ ${ }^{1}$ Water Science and Engineering Dept., Faculty of Agriculture, Ferdowsi University of Mashhad, \\ Mashhad, 91779-48974, Iran \\ ${ }^{2}$ Water Engineering Dept., College of Agriculture, Isfahan Univ. of Technology, \\ Isfahan, 84156-83111, Iran \\ ${ }^{3}$ Agronomy and Plant Breeding Dept., College of Agriculture, Isfahan Univ. of Technology, \\ Isfahan, 84156-83111, Iran
}

\begin{abstract}
Water scarcity is one the main problems of sustainable agriculture. One way to overcome this problem is to use wastewaters for irrigation. To determine the effect of salinity and sodicity of municipal wastewater as irrigation water and leaching application, on some of common soil chemical properties and consequently on growth performance of corn, a soil column experiment was conducted with sandy clay loam soil. Nine treatments including wastewaters with three different salinity levels: 1, 4.7 (blending of 1 and $9 \mathrm{dS} / \mathrm{m}$ wastewaters with 1:1 ratio), $9 \mathrm{dS} / \mathrm{m}$, and three levels of leaching fractions: 0, 15 and 30 percent were arranged in a factorial experiment with three replication. Results show that at first and last layer of the soil, the effect of 30 percent leaching on soil salinity (ECe) was statistically significant only for irrigation with $9 \mathrm{dS} / \mathrm{m}$ wastewater. Application of the 15 and 30 percent leaching fraction for irrigation with $4.7 \mathrm{dS} / \mathrm{m}$ wastewater $(S A R=8.2)$ significantly reduced soil SAR at first layer of the soil. The application 30 percent leaching fraction significantly increased corn dry yield for irrigation with all of three wastewaters. There was no significant difference between effects of irrigation with 4.7 dS/m wastewater with the 15 and 30 percent leaching fraction and irrigation with $1 \mathrm{dS} / \mathrm{m}$ wastewater with 0 and 15 percent leaching fraction on IWUE. Results show that with combination of leaching method and reduction wastewater salinity through blending of wastewaters for irrigation with saline sodic wastewater, high corn biomass can be achieved, without any significant difference in comparison with non-saline or non-sodic wastewater.
\end{abstract}

Keywords: Corn yield, irrigation, leaching, salinity, sodicity, wastewater

\section{Introduction}

Increase of population, has made renewable water resources to be limited specially in arid and semi-arid parts of the world (Steduto et al., 2012). In 2025, more than 1 billion people who live in arid or semi-arid areas of world will suffer severe water scarcity (Seckler et al., 1999). Iran is among the countries around the world which suffers severe shortage of freshwater (Shahabfar et al., 2012). One way of dealing with such problem is to use marginal waters for irrigation such as industrial wastewater, saline groundwater and agricultural drainage water (Murtaza et al., 2006; Chang and Ma, 2012; Chen et al., 2013). These marginal waters contain different amounts of soluble salts and irrigation with these waters may have adverse effect on fertility of the soils. Adverse impact of saline water application in soil is related to osmotic pressure. Salts accumulation in the soil by adsorption of water prevents plants root from smooth water uptake that consequently affects plant growth performance (Katerji, 2003; Kirkham, 2005). Saline irrigating water also may decline soil performance through soil sodicity induced by irrigation that causes soil structural problems and specific ion effect on crops that can be a hazardous for human or crops health (Shainberg and Letey, 1984; Page et al., 1996; Qadir and Oster, 2004; Grattan et al., 2015). Estimates indicate that 34 million hectare, including 4.1 million hectare of irrigated lands in Iran suffering from different kinds of salinization. The annual economy loss due to salinization is more than US\$ 1 billion (Qadir et al., 2008). Investigation indicates that corn which is one of common crops in Iran, has been produced in 2013 more than ever (Anonymous, 2013). Corn maize seasonal evapotranspiration as reported by some researchers was about $667 \mathrm{~mm}$ up to $1003 \mathrm{~mm}$ depending on climate conditions. So corn can be categorized as a high water demanding plant (Musick and Duseek, 1980; Eck, 1984). Results of some researches indicated that using marginal waters like industrial wastewater and saline groundwater as irrigation water caused yield reduction of plants such as corn, olive, cucumber and grapevine (Amer 2010; Kang et al., 2010; Wan et al., 2010; Ben Ahmed et al., 2012; Bame et al., 2014). Impacts of wastewater

*Email: farzam.moghbel2@gmail.com 
irrigation on soil chemical components have been reported by Sou/Dakouré et al. (2013) and Bedbabis et al. (2014, 2015). The increase of soil salinity and sodicity and decrease of soil infiltration rate has been observed by Bedbabis et al., 2014 after long-term irrigation with wastewater. Researchers concluded that irrigation with hyper sodic wastewater destroyed soil structure especially in sub-horizon of soil (Sou/Dakouré et al., 2013; Bedbabis et al., 2014; Bedbabis et al., 2015). Researchers have investigated wastewater application effects on soil ions concentration of $\mathrm{Na}^{+}, \mathrm{Ca}^{+}, \mathrm{Mg}^{+}, \mathrm{K}^{+}$and on heavy metals accumulation in the soils and plant tissues. It has been concluded that diverse effects of wastewater irrigation is related to initial condition of soil and irrigation water with respect to their chemical properties (Heidarpour et al., 2007; Mohammad Rusan et al., 2007; Jalali et al., 2008). In addition to fertilizing benefits of wastewater irrigation, which is mainly because of nitrate $\left(\mathrm{NO}_{3}{ }^{-}\right)$and phosphor $(\mathrm{P})$, leaching of these supplement compounds to groundwater supplies cause groundwater pollution (Magesana et al, 1998; Batziaka et al., 2008; Blum et al., 2013; Zhang et al., 2013; -Lal et al., 2015; Marofi et al., 2015). As indicated by Oster and Grattan (2002), use of marginal water like salinesodic drainage water for irrigation needs proper management of soil and crop. Blending of marginal waters with good quality waters, cycling use of marginal waters and good quality water and sequential use of marginal waters are management manners of controlling effects of reclaimed water irrigation on soil salinity and crop yield (Grattan et. al., 2000). Blending of waters with different qualities in order to use as irrigation water has been tested by Gengmao et al. (2010); Grattan et al. (2008), which both of these researches demonstrated that with proper dilution of hyper saline water, irrigation of salt tolerant crops can successfully achieve sufficient yield which is economically beneficial. Choudhary et al. (2006) investigated effectiveness of cycling method in order to use sodic water for long term irrigating of sunflower in agriculture lands. For dealing with soil salinity and sodicity as consequences of irrigation with saline groundwater or drainage water some results have been published by Mostafazadeh-Fard et al. (2009), Heidarpour et al. (2009) and Heakal et al. (1990) which all of them proved that with increasing leaching fractions, lower soil salinity and higher yield could be achieved. Recently researchers have shown that impact of applying some amendments in combination with leaching methods were reliable for reclamation of sodic soils (Chaganti et al., 2015; Chaganti and Crohn, 2015). Many aspects of salinity and sodicity managements in order to use marginal water like wastewater are still unknown. The aim of this study was to determine effects of using saline-sodic municipal wastewater for irrigation with proper management on soil chemical properties and corn yield.

\section{Materials and Methods}

\section{Soil and column preparation}

The soil columns experiment was conducted in greenhouse area at Isfahan University of Technology in 2014. The columns were made of polyethylene (PE) with $60 \mathrm{~cm}$ height and $25 \mathrm{~cm}$ inside diameter. Coarse gravels with thickness of $2 \mathrm{~cm}$ were used as filters at bottom of columns to allow drainage. All columns were filled with soil and the soil height inside each column was $40 \mathrm{~cm}$. Upper part of columns with depth of about $20 \mathrm{~cm}$ were left for application of irrigation water. An agricultural soil with texture of sandy clay loam (Table 1) and with wet bulk density of $1.8 \mathrm{~g} / \mathrm{cm}^{3}$ was used for the experiment. The soil was obtained from Mahiar agricultural field located at south of Isfahan province, Iran. The initial physical and chemical characteristics of the soil are presented in Table 1. According to Table 1, the soil is categorized as non-saline or non - sodic soil.

\section{Sowing of plant seed}

Planting of corn seeds was done after soil filling of the columns. KSC 704 forage maize (corn) hybrid was the type of plant seed which was sown in this experiment. At the beginning of the experiment five seed were sown in each column and columns were irrigated with municipal freshwater but after reaching 4 leaves stage of plant growth, the number of plants were reduced to two plants in each columns and experimental treatments were applied.

\section{Experimental design and treatments}

A factorial experiment with completely randomized design based was used with three replications for each treatment. As shown in Table 2, the treatments were three types of wastewater as irrigation water with classification of saline-sodic with EC of $9 \mathrm{dS} / \mathrm{m}\left(\mathrm{W}_{1}\right)$, non-saline or nonsodic with EC of $1 \mathrm{dS} / \mathrm{m}\left(\mathrm{W}_{2}\right)$ and saline with EC of 4.7 $\mathrm{dS} / \mathrm{m}\left(\mathrm{W}_{3}\right)$. The sub-treatments were leaching fractions of 0 $\%\left(\mathrm{LF}_{1}\right), 15 \%\left(\mathrm{LF}_{2}\right)$ and $30 \%\left(\mathrm{LF}_{3}\right)$. The saline-sodic wastewater $\left(\mathrm{W}_{1}\right)$ was obtained from municipal wastewater of Varzaneh city located at southeast of Isfahan Province of Iran. The non-saline or non-sodic $\left(\mathrm{W}_{2}\right)$ wastewater was obtained from treatment lagoon of Isfahan University of Technology's wastewater plan. The saline wastewater $\left(\mathrm{W}_{3}\right)$ was obtained by blending $\mathrm{W}_{1}$ and $\mathrm{W}_{2}$ wastewaters with 1:1 ratio. The leaching fraction was considered in gross depth of irrigation water which is:

$d g=\frac{d n}{\left[1-\pi \cdot E_{i n}\right.}$

(1) 
Table 1: The initial soil physical and chemical properties

\begin{tabular}{|c|c|c|c|c|c|}
\hline \multicolumn{6}{|c|}{ Soil physical characteristics } \\
\hline Sand & Silt & & Clay & \multirow{2}{*}{ Bulk density $(\mathrm{g} / \mathrm{cm} 3)$} & \multirow[t]{2}{*}{ Soil texture } \\
\hline & \multicolumn{3}{|l|}{$(\%)$} & & \\
\hline 73 & 7 & & 23 & & Sandy clay loam \\
\hline \multirow{2}{*}{\multicolumn{6}{|c|}{$\begin{array}{l}\text { Soil chemical characteristics } \\
\end{array}$}} \\
\hline \multirow[t]{2}{*}{$\mathrm{EC}(\mathrm{dS} / \mathrm{m})$} & \multirow[t]{2}{*}{$\mathrm{pH}$} & & Ions $(\mathrm{meq} / \mathrm{L})$ & & USSL classification \\
\hline & & $\mathrm{Na}+$ & $\mathrm{Ca} 2++\mathrm{Mg} 2+$ & $\mathrm{K}+$ & \\
\hline 2.13 & 8.5 & 9.62 & 9 & 2.20 & Non-saline or non-sodic soil \\
\hline
\end{tabular}

Table 2: Chemical properties of wastewaters used as irrigation water

\begin{tabular}{lllllllll}
\hline $\mathrm{EC}(\mathrm{dS} / \mathrm{m})$ & $\mathrm{pH}$ & \multicolumn{3}{c}{ Ions (meq/L) } & $\mathrm{NO}_{3}{ }^{-} \mathrm{N}\left(\mathrm{mg} . \mathrm{L}^{-1}\right)$ & $\mathrm{SAR}$ & Classification \\
\cline { 3 - 5 } & & $\mathrm{Na}^{+}$ & $\mathrm{Ca}^{2+}+\mathrm{Mg}^{2+}$ & $\mathrm{K}^{+}$ & & & \\
\hline $\mathrm{W}_{1}$ & 9 & 8.7 & 45.37 & 24 & 1.2 & 13.9 & 13.1 & Saline-Sodic \\
$\mathrm{W}_{2}$ & 1 & 8.5 & 4.29 & 6.2 & 0.43 & 14.62 & 2.44 & Non-saline or non-sodic \\
$\mathrm{W} 3$ & 4.7 & 8.56 & 22.28 & 14.8 & 0.77 & 14.10 & 8.19 & Saline \\
\hline
\end{tabular}

$\mathrm{W}_{1}=$ Varzaneh wastewater, $\mathrm{W}_{2}=$ Isfahan university of technology's wastewater, $\mathrm{W}_{3}=$ blended wastewater (blending of $\mathrm{W}_{1}$ and $\mathrm{W}_{2}$ wastewaters with 1:1 ratio), $\mathrm{SAR}=$ sodium adsorption ratio

where $\mathrm{dg}$ is gross depth of irrigation water, dn is net depth of irrigation water, LF is leaching fraction, and $\mathrm{Ea}$ is application efficiency. $\mathrm{Ea}$ is assumed as 1, because irrigation was done soil columns and no loss was due to application of water (Keller and Bliesner 1990).

\section{Irrigation operation}

Irrigation was applied following depletion of $50 \%$ of available water, based on reduction of soil column weight. All columns were weighed daily to determine when to irrigate. The soil columns were irrigated for 3 months using above wastewaters and leaching fractions.

\section{Yield and yield components measurement}

About three days before the termination of the process, leaf area and some other plant components like stem diameter and stem height have been measured. All of plants had been cut from their base on the soil surface and soil columns were emptied gradually to prevent the root from being harmed. For measuring of corn yield, plants were weighted two times: before and after being dried. All of roots had been revealed from the columns and their volumes were recorded by Archimedes changing of water volume method. Irrigation water use efficiency (IWUE) as ratio of plant dry weight to the amount of water applied during irrigation season was calculated using the following equation (Payero et. al., 2008):

$$
\text { IWUE }=\frac{Y}{I}
$$

where $\mathrm{Y}=$ yield $\left(\mathrm{kg} \mathrm{ha}^{-1}\right)$ and $\mathrm{I}=$ seasonal irrigation applied water $(\mathrm{mm})$.
In the above relation, dry weight of corn was considered for yield term because one of main aims of planting forage corn in agricultural area of Isfahan province is feeding of livestock with corn leaves.

\section{Soil sampling and measurement}

Soil sampling was done simultaneously with emptying of the soil columns. Soil samples at three depths of $0-10 \mathrm{~cm}, 10-25 \mathrm{~cm}$ and $25-40 \mathrm{~cm}$ were obtained. The soil samples were air dried, passed through $2 \mathrm{~mm}$ sieve and soil saturated paste extract was obtained. The electrical conductivity of soil saturated paste extract was measured by Ohaus Starter 3000C electrical conductivity meter. The $\mathrm{pH}$ of soil saturated paste extract was measured by Metrohum $\mathrm{pH}$ meter. Sodium adsorption ration was calculated using the following relation:

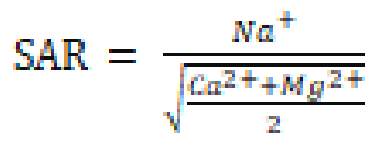

where $\mathrm{Na}^{+}, \mathrm{Ca}^{2+}$ and $\mathrm{Mg}^{2+}=$ concentration $(\mathrm{meq} / \mathrm{l})$ of sodium, calcium and magnesium in soil saturated paste extract. Sodium concentrations were measured by flame photometer. Other soil cations such as $\mathrm{Ca}^{2+}$ and $\mathrm{Mg}^{2+}$ were also measured for soils saturated paste extract using titration method ( Estefan and Sommer, 2013). Potassium $\left(\mathrm{K}^{+}\right)$concentration as an element, which has potential to be reason of clay swelling and dispersion of soil content, was measured by flame photometer (Marchuk and Rengasamy, 2010). 
Table 3: Mean comparisons of the effects of treatments on soil $\mathrm{EC}_{\mathrm{e}}(\mathrm{dS} / \mathrm{m})$

\begin{tabular}{|c|c|c|c|c|c|c|}
\hline \multirow[t]{2}{*}{ Soil depth } & \multicolumn{3}{|c|}{ Irrigation water salinity } & \multicolumn{3}{|c|}{ Leaching fraction } \\
\hline & W1 & W2 & W3 & LF1 & LF2 & LF3 \\
\hline $0-10 \mathrm{~cm}$ & $5.26 \mathrm{a}$ & $1.49 \mathrm{c}$ & $2.92 \mathrm{~b}$ & $3.84 \mathrm{a}$ & $3.39 \mathrm{ab}$ & $2.45 \mathrm{~b}$ \\
\hline $10-25 \mathrm{~cm}$ & $5.60 \mathrm{a}$ & $1.51 \mathrm{~b}$ & $5.30 \mathrm{a}$ & $3.79 \mathrm{a}$ & $4.37 \mathrm{a}$ & $4.26 \mathrm{a}$ \\
\hline $25-40 \mathrm{~cm}$ & $6.30 \mathrm{a}$ & $1.65 \mathrm{c}$ & $4.84 \mathrm{~b}$ & $3.68 \mathrm{~b}$ & $3.94 \mathrm{~b}$ & $5.16 \mathrm{a}$ \\
\hline
\end{tabular}

Note: The values followed by at least one same character are not statistically different at $5 \%$ probability level. $\mathrm{W}_{1}=$ varzaneh wastewater $(9 \mathrm{dS} / \mathrm{m}), \mathrm{W}_{2}=$ Isfahan university of technology's wastewater $(1 \mathrm{dS} / \mathrm{m}), \mathrm{W}_{3}=$ blended wastewater (blending of $\mathrm{W}_{1}$ and $\mathrm{W}_{2}$ wastewaters with 1:1 ratio, $4.7 \mathrm{dS} / \mathrm{m}$ ). $\mathrm{LF}_{1}=0 \%$ leaching fraction, $\mathrm{LF}_{2}=15 \%$ leaching fraction, $\mathrm{LF}_{3}=30 \%$ leaching fraction

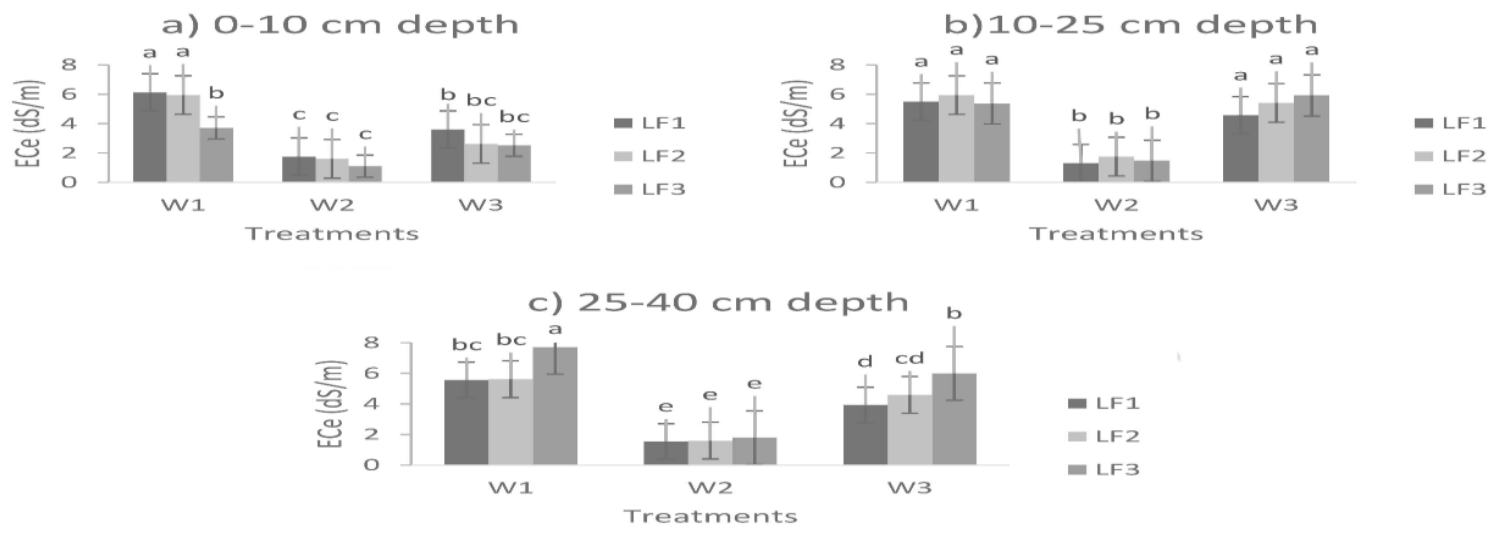

Figure 1: Interaction effects of the treatments on soil ECe at the depth of a) 0-10, b) $10-25$ and c) $25-40 \mathrm{~cm}$

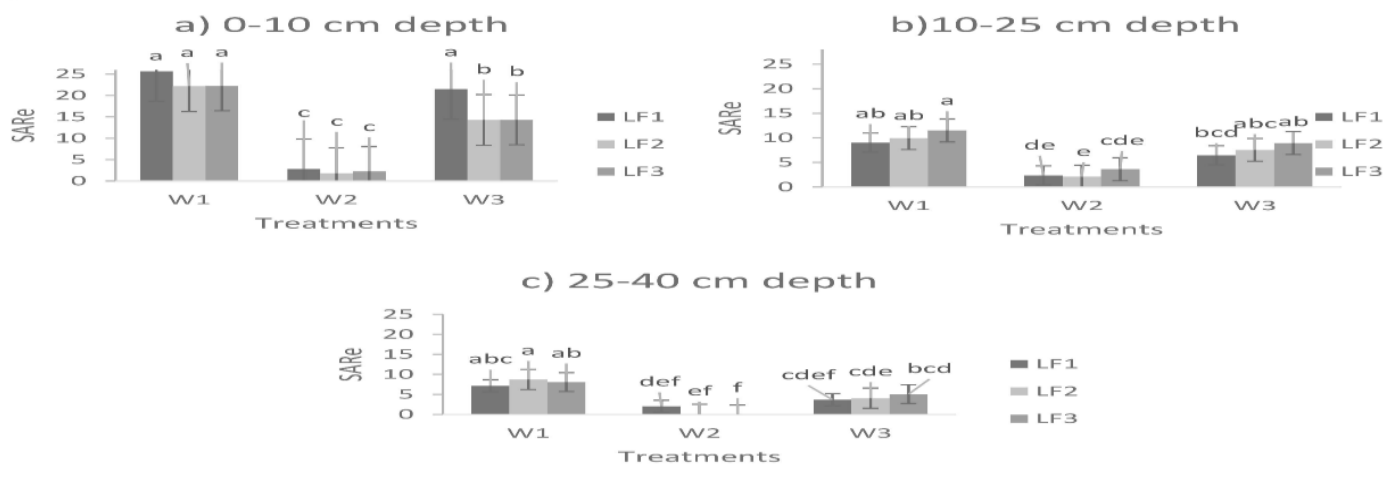

Figure 2: The interaction effects of the treatments on soil SAR at depth of a) 0-10, b) 10-25 and c) $25-40 \mathrm{~cm}$

\section{Statistical analysis}

Statistical analysis has been done using SAS 9.2 and Statistix 8.0 software. LSD (least significant difference) and Duncan Multiple Range test methods have been used to determine the statistical differences between mean effects of the treatments on soil chemical characteristics and corn yield.

\section{Results and Discussion Soil ECe (dS/m)}

Before the start of the experiment, the initial mean soil ECe was about $2.13 \mathrm{dS} / \mathrm{m}$. The soil analysis at the end of study showed that irrigation water salinities and leaching fractions had significantly influenced soil salinities for all soil depths (Table 3). Increasing irrigation water salinity 
caused increase in soil ECe which is correspond with results obtained by Ben Ahmed et al. (2012). The soil salinity of $\mathrm{W}_{3}$ treatment was significantly less than soil salinity of $\mathrm{W}_{1}$ treatment. Leaching treatments significantly affected soil salinity in soil depths of 0-10 and $25-40 \mathrm{~cm}$. The leaching fractions of 15 and 30 percent caused salts to be removed from upper parts of the root zone to the lower parts. Ayers and Westcot (1985) reported similar results. In treatments without leaching fractions, salinity accumulated in the upper parts of the soil $(0-10 \mathrm{~cm})$. This result is consistent with results reported by Li et al. (2015). Mean comparisons show that 30 percent leaching fraction, reduces soil salinity in the upper part of soil 25 percent more than the 15 percent leaching fraction (Table 3 ).
Similar results were obtained by Heakal et al. (1990). Interaction effects of irrigation water salinities and leaching levels on soil salinity are presented in Fig.1. Interaction effects results show that at the depth of 0-10 and $25-40 \mathrm{~cm}$, the effect of 30 percent leaching was statistically significant only for irrigation with $\mathrm{W}_{1}$ wastewater. Results indicates that the application of 30 percent leaching for irrigation with $\mathrm{W}_{1}$ wastewater did not significantly reduced soil salinity at $0-10 \mathrm{~cm}$ soil depth in comparison with $\mathrm{W}_{3}$ treatments (with or without leaching application).

\section{Soil pH}

As shown in Table 4, irrigation water salinities significantly decreased soil $\mathrm{pH}$ at soil depths of $10-25 \mathrm{~cm}$

Table 4: Mean comparisons of the effects of treatments on soil $\mathrm{pH}(\mathrm{p}<0.05)$

\begin{tabular}{|c|c|c|c|c|c|c|}
\hline \multirow[t]{2}{*}{ Soil depth } & \multicolumn{3}{|c|}{ Irrigation water salinity } & \multicolumn{3}{|c|}{ Leaching fraction } \\
\hline & W1 & W2 & W3 & LF1 & LF2 & LF3 \\
\hline $0-10 \mathrm{~cm}$ & $8.53 \mathrm{a}$ & $8.45 \mathrm{a}$ & $8.49 \mathrm{a}$ & $8.45 \mathrm{a}$ & $8.54 \mathrm{a}$ & $8.47 \mathrm{a}$ \\
\hline $10-25 \mathrm{~cm}$ & $8.40 \mathrm{~b}$ & $8.75 \mathrm{a}$ & 8. $40 \mathrm{~b}$ & $8.60 \mathrm{a}$ & $8.35 \mathrm{~b}$ & $8.61 \mathrm{a}$ \\
\hline $25-40 \mathrm{~cm}$ & $8.19 \mathrm{~b}$ & $8.39 \mathrm{a}$ & $8.10 \mathrm{~b}$ & $8.26 \mathrm{a}$ & $8.21 \mathrm{a}$ & $8.21 \mathrm{a}$ \\
\hline
\end{tabular}

Note: The values followed by at least one same character are not statistically different at $5 \%$ probability level. $\mathrm{W}_{1}=$ varzaneh wastewater $(9 \mathrm{dS} / \mathrm{m}), \mathrm{W}_{2}=$ Isfahan university of technology's wastewater $(1 \mathrm{dS} / \mathrm{m}), \mathrm{W}_{3}=$ blended wastewater (blending of $\mathrm{W}_{1}$ and $\mathrm{W}_{2}$ wastewaters with 1:1 ratio, $4.7 \mathrm{dS} / \mathrm{m}$ ). $\mathrm{LF}_{1}=0 \%$ leaching fraction, $\mathrm{LF}_{2}=15 \%$ leaching fraction, $\mathrm{LF}_{3}=30 \%$ leaching fraction

Table 5: Mean comparison of the effects of treatments on soil $\mathrm{SAR}(\mathrm{p}<0.05)$

\begin{tabular}{|c|c|c|c|c|c|c|}
\hline \multirow[t]{2}{*}{ Soil depth } & \multicolumn{3}{|c|}{ Irrigation water salinity/sodicity } & \multicolumn{3}{|c|}{ Leaching fraction } \\
\hline & W1 & W2 & W3 & LF1 & LF2 & LF3 \\
\hline $0-10 \mathrm{~cm}$ & $23.33 \mathrm{a}$ & $2.30 \mathrm{c}$ & $16.67 \mathrm{~b}$ & $16.61 \mathrm{ab}$ & $12.75 \mathrm{~b}$ & $12.93 \mathrm{~b}$ \\
\hline $10-25 \mathrm{~cm}$ & $10.16 \mathrm{a}$ & $2.69 \mathrm{~b}$ & $7.64 \mathrm{a}$ & $5.59 \mathrm{a}$ & $6.53 \mathrm{a}$ & $8.02 \mathrm{a}$ \\
\hline $25-40 \mathrm{~cm}$ & $8.02 \mathrm{a}$ & $0.56 \mathrm{c}$ & $4.26 \mathrm{~b}$ & $4.28 \mathrm{a}$ & $4.30 \mathrm{a}$ & $4.25 \mathrm{a}$ \\
\hline
\end{tabular}

Note: The values followed by at least one same character are not statistically different at $5 \%$ probability level. $\mathrm{W}_{1}=$ varzaneh wastewater $(9 \mathrm{dS} / \mathrm{m}), \mathrm{W}_{2}=$ Isfahan university of technology's wastewater $(1 \mathrm{dS} / \mathrm{m}), \mathrm{W}_{3}=$ blended wastewater (blending of $\mathrm{W}_{1}$ and $\mathrm{W}_{2}$ wastewaters with 1:1 ratio, $4.7 \mathrm{dS} / \mathrm{m}$ ). $\mathrm{LF}_{1}=0 \%$ leaching fraction, $\mathrm{LF}_{2}=15 \%$ leaching fraction, $\mathrm{LF}_{3}=30 \%$ leaching fraction

Table 6: Mean comparison of the effects of treatments on soil potassium concentration meq $L^{-1}(p<0.05)$

\begin{tabular}{|c|c|c|c|c|c|c|}
\hline \multirow[t]{2}{*}{ Soil depth } & \multicolumn{3}{|c|}{$\begin{array}{c}\text { Irrigation water salinity/ potassium } \\
\text { concentration }\end{array}$} & \multicolumn{3}{|c|}{ Leaching fraction } \\
\hline & W1 & W2 & W3 & LF1 & LF2 & $\overline{L F 3}$ \\
\hline $0-10 \mathrm{~cm}$ & $1.44 \mathrm{a}$ & $1.21 \mathrm{a}$ & $0.95 \mathrm{a}$ & $1.18 \mathrm{a}$ & $1.29 \mathrm{a}$ & $1.15 \mathrm{a}$ \\
\hline $10-25 \mathrm{~cm}$ & $1.51 \mathrm{a}$ & $1.07 \mathrm{a}$ & $1.58 \mathrm{a}$ & $1.28 \mathrm{a}$ & $1.52 \mathrm{a}$ & $1.36 \mathrm{a}$ \\
\hline $25-40 \mathrm{~cm}$ & $1.14 \mathrm{a}$ & $0.68 \mathrm{~b}$ & $1.09 \mathrm{a}$ & $0.90 \mathrm{a}$ & $0.98 \mathrm{a}$ & $1.03 \mathrm{a}$ \\
\hline
\end{tabular}

Note: The values followed by at least one same character are not statistically different at $5 \%$ probability level. $\mathrm{W}_{1}=$ varzaneh wastewater $(9 \mathrm{dS} / \mathrm{m}), \mathrm{W}_{2}=$ Isfahan university of technology's wastewater $\left(1 \mathrm{dS} / \mathrm{m}, \mathrm{W}_{3}=\right.$ blended wastewater (blending of $\mathrm{W}_{1}$ and $\mathrm{W}_{2}$ wastewaters with 1:1 ratio, $4.7 \mathrm{dS} / \mathrm{m}$ ). $\mathrm{LF}_{1}=0 \%$ leaching fraction, $\mathrm{LF}_{2}=15 \%$ leaching fraction, $\mathrm{LF}_{3}=30 \%$ leaching fraction 
and $25-40 \mathrm{~cm}$. Leaching treatments significantly affected soil $\mathrm{pH}$ only at $10-25 \mathrm{~cm}$ soil depth. Results indicate that for $\mathrm{W}_{2}$ as compared to $\mathrm{W}_{1}$ and $\mathrm{W}_{3}$ the soil $\mathrm{pH}$ at soil depth of $10-25 \mathrm{~cm}$ have more $\mathrm{pH}$ values.

\section{Sodium adsorption ratio (SAR)}

Different levels of irrigation water sodicity significantly affected sodium adsorption ratio (SAR) of the soil (Table 5). Leaching effects on soils SAR were significant only at soil depth of $0-10 \mathrm{~cm}$. Irrigation water sodicity levels significantly increased soil SAR at all three soil depth. In comparison with $\mathrm{W}_{1}$ treatment, the $\mathrm{W}_{3}$ treatment caused 28 and 50 percent reduction in SAR at soil depths of $0-10 \mathrm{~cm}$ and $25-40 \mathrm{~cm}$, respectively. So blending method can be used successfully to reduce soil sodicity impacts of sodic wastewater. This result is consistent with the results of Grattan et al. (2008). Two levels of leaching (15 and 30 percent leaching), caused 23 percent reduction of SAR at soil depth of $0-10 \mathrm{~cm}$. Increasing leaching fraction from 15 to 30 percent did not significantly affect soil SAR. So, increasing leaching level is not recommended without using of calcium amendments. The leaching effects results correspond with results obtained by Chaganti et al. (2015). Results of interaction effects of the treatments on soil SAR are presented in Fig. 2. Interaction effects results show that application of the 15 and 30 percent leaching fraction for irrigation with $\mathrm{W}_{3}$ wastewater significantly reduced soil SAR at the depth of $0-10 \mathrm{~cm}$ in comparison with $\mathrm{W}_{1}$ treatments (with or without leaching application). As Chaganti et al. (2015) reported, effectiveness of leaching application has been observed even without any supplement.

\section{Potassium (K+)}

Different levels of irrigation water salinity or its potassium concentrations $(\mathrm{K})$ had significant effect on soil potassium concentration at depth of $25-40 \mathrm{~cm}$ (Table 6). Leaching levels did not have significant impact on soil potassium concentration. The potassium concentration effect on soil physical properties related to soil's clay minerals may cause reduction in soil hydraulic conductivity (Arienzo et. al., 2012). Because of low accumulation of potassium in soil profile, potassium concentration did not affect soil hydraulic conductivity.

\section{Growth components of corn \\ Dry weight yield}

As shown in Table 7, the increase in irrigation water salinity causes significant decrease in corn dry yield. The least corn yield was obtained with $\mathrm{W}_{1}(9 \mathrm{dS} / \mathrm{m})$ treatment. This result is similar with results obtained by Wan et al. (2010) and Mostafazadeh-Fard et al. (2009). Mean comparison of corn biomasses (dry yield) indicates that $\mathrm{W}_{3}$ treatment significantly increased corn dry yield in comparison with $\mathrm{W}_{1}$ treatment. Therefore, it can be concluded that blending of saline wastewater with nonsaline wastewater can be an effective way in order to improve dry weight yield of corn plant. Results of leaching effects on corn dry yield show that 15 and 30 percent leaching increased corn biomass about 19 and 66 percent, respectively. Leaching can be an effective way to increase corn dry yield for irrigation with saline and sodic wastewaters. Mostafazadeh-Fard et al. (2009) and Heidarpour et al. (2009) have reported similar results for irrigation of winter wheat with saline drainage water. Results of interaction effects of the treatments (Table 8) show that application of 15 and 30 percent leaching fraction increased corn dry yield for irrigation with all of three wastewaters in comparison with treatments without leaching application but only the 30 percent leaching effect was statistically significant. Irrigation with the $\mathrm{W}_{3}$ wastewater (blended wastewater) without leaching application significantly increased corn dry yield, in comparison with $\mathrm{W}_{1}$ wastewater treatment with 0 and 15 percent leaching application. Plant yield prediction based on prevailing soil condition is truly important. Maas and Hoffman (1977) presented a liner equation between plant yield and ECe but specific-ion impacts should be considered too. A linear regression was developed between corn relative yields ( $\mathrm{Yr}$ ) and ECe. In addition, another linear regression was developed between relative yield (Yr) and sodium adsorption ratio (SAR) of soil saturated extract paste. Regression analysis showed more variation for $\mathrm{Yr}$ and SARe $\left(R^{2}=0.82\right)$ than $\mathrm{Yr}$ and ECe $\left(\mathrm{R}^{2}=0.74\right)$. These results are presented in Figs. 3 and 4. It can be concluded that for situations when corn is irrigated by sodic water and soil SAR is moderate or soil is sodic, it will be better to predict corn yield base on prevailing sodicity level of the soil instead of salinity level.

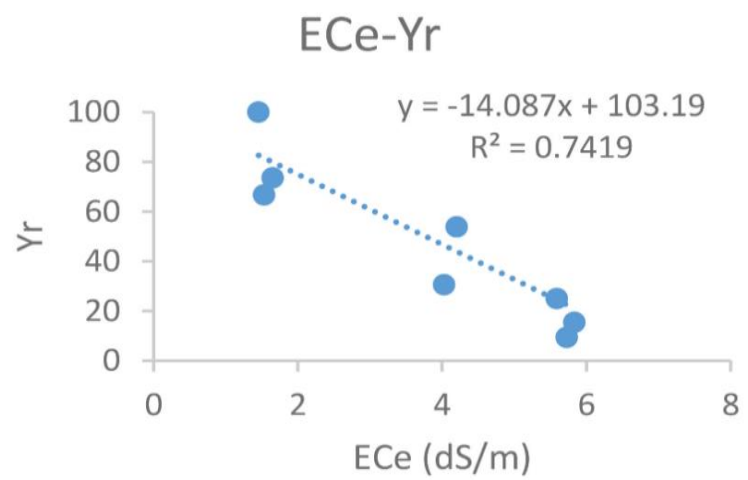

Figure 3: Linear relationship between soil $\mathrm{ECe}-$ and forage corn relative yield 


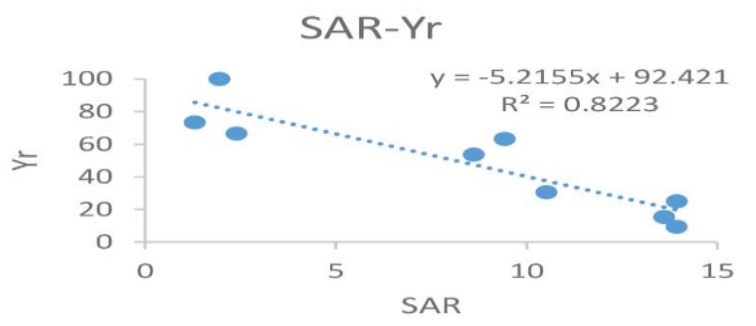

Figure 4: Linear relationship between soil SAR and forage corn relative yield

\section{Plant Fresh Biomass}

Irrigation water salinities and leaching fractions significantly affected plant wet yield (Table 7). A significant reduction of plant wet weight has been observed as consequences of increasing irrigation water salinity. Irrigating with $\mathrm{W}_{3}$ water (blending treatment) significantly increased corn wet yield in comparison with $\mathrm{W}_{1}$ treatment. The 15 and 30 percent leaching fractions, significantly increased corn wet weight about 26 and 54 percent, respectively. Results of interaction effects of treatments (Table 8) show that application of the 15 and 30 percent leaching for irrigation with $\mathrm{W}_{3}$ wastewater significantly increased corn wet weight in comparison with $\mathrm{W}_{1}$ treatments (with or without leaching application). Results of interaction effects of treatments show that the 30 percent leaching application for irrigation with all of three wastewaters significantly increased plant wet weight in comparison with treatments, which leaching was not

Table 7: Mean comparison of the effects of treatments on corn growth components $(p<0.05)$

\begin{tabular}{llllllll}
\hline & \multicolumn{3}{c}{ Irrigation water salinity } & & \multicolumn{3}{c}{ Leaching fraction } \\
\cline { 2 - 3 } \cline { 6 - 8 } & W1 & W2 & W3 & & LF1 & LF2 & LF3 \\
\hline Dry Weight (g) & $19.45 \mathrm{c}$ & $58.70 \mathrm{a}$ & $41.69 \mathrm{~b}$ & & $31.11 \mathrm{~b}$ & $37.04 \mathrm{~b}$ & $51.69 \mathrm{a}$ \\
Wet Weight (g) & $31.54 \mathrm{c}$ & $77.81 \mathrm{a}$ & $61.10 \mathrm{~b}$ & & $44.87 \mathrm{c}$ & $56.49 \mathrm{~b}$ & $69.10 \mathrm{a}$ \\
IWUE (kg/ha.mm) & $6.66 \mathrm{c}$ & $20.68 \mathrm{a}$ & $14.64 \mathrm{~b}$ & & $12.23 \mathrm{a}$ & $13.29 \mathrm{ab}$ & $16.46 \mathrm{~b}$ \\
Stem Diameter (mm) & $10.96 \mathrm{c}$ & $15.91 \mathrm{a}$ & $14.35 \mathrm{~b}$ & & $10.70 \mathrm{~b}$ & $14.85 \mathrm{a}$ & $15.66 \mathrm{a}$ \\
Stem Height (cm) & $24.68 \mathrm{c}$ & $67.36 \mathrm{a}$ & $37.13 \mathrm{~b}$ & & $31.68 \mathrm{c}$ & $45.25 \mathrm{~b}$ & $52.24 \mathrm{a}$ \\
Leaf area (cm2) & $50.54 \mathrm{c}$ & $89.10 \mathrm{a}$ & $61.58 \mathrm{~b}$ & & $51.78 \mathrm{c}$ & $63.67 \mathrm{~b}$ & $85.76 \mathrm{a}$ \\
Root Volume (mm3) & $7.49 \mathrm{~b}$ & $29.06 \mathrm{a}$ & $17.04 \mathrm{~b}$ & & $14.16 \mathrm{a}$ & $17.17 \mathrm{a}$ & $22.27 \mathrm{a}$ \\
\hline
\end{tabular}

Note: The values followed by at least one same character are not statistically different at $5 \%$ probability level. $\mathrm{W}_{1}=$ varzaneh wastewater $(9 \mathrm{dS} / \mathrm{m}), \mathrm{W}_{2}=$ Isfahan university of technology's wastewater $(1 \mathrm{dS} / \mathrm{m}), \mathrm{W}_{3}=$ blended wastewater (blending of $\mathrm{W}_{1}$ and $\mathrm{W}_{2}$ wastewaters with 1:1 ratio, $4 / 7 \mathrm{dS} / \mathrm{m}$ ). $\mathrm{LF}_{1}=0 \%$ leaching fraction, $\mathrm{LF}_{2}=15 \%$ leaching fraction, $\mathrm{LF}_{3}=30 \%$ leaching fraction

Table 8: Mean comparison of the interaction effects of treatments on growth components of corn $(p<0.05)$

Corn Growth Components

\begin{tabular}{lllllllll}
\cline { 3 - 7 } Treatments & EC(dS/m) & $\begin{array}{l}\text { Dry Weight } \\
(\mathrm{g})\end{array}$ & $\begin{array}{l}\text { Wet } \\
\text { Weight } \\
(\mathrm{g})\end{array}$ & $\begin{array}{l}\text { IWUE } \\
(\mathrm{kg} / \mathrm{ha} \cdot \mathrm{mm})\end{array}$ & $\begin{array}{l}\text { Stem } \\
\text { Diameter } \\
(\mathrm{mm})\end{array}$ & $\begin{array}{l}\text { Stem } \\
\text { Height } \\
(\mathrm{cm})\end{array}$ & $\begin{array}{l}\text { Leaf area } \\
(\mathrm{cm})\end{array}$ & $\begin{array}{l}\text { Root } \\
\text { Volume } \\
(\mathrm{mm} 3)\end{array}$ \\
\hline W1LF1 & 9 & $10.56 \mathrm{e}$ & $20.54 \mathrm{f}$ & $4.17 \mathrm{f}$ & $5.68 \mathrm{~g}$ & $11.24 \mathrm{e}$ & $27.03 \mathrm{e}$ & $6.16 \mathrm{c}$ \\
W1LF2 & 9 & $15.22 \mathrm{de}$ & $29.21 \mathrm{ef}$ & $5.45 \mathrm{ef}$ & $13.75 \mathrm{de}$ & $24.57 \mathrm{~d}$ & $53.63 \mathrm{~d}$ & $8.82 \mathrm{bc}$ \\
W1LF3 & 9 & $32.56 \mathrm{~cd}$ & $44.87 \mathrm{de}$ & $10.35 \mathrm{de}$ & $13.45 \mathrm{e}$ & $38.24 \mathrm{c}$ & $70.97 \mathrm{bcd}$ & $7.49 \mathrm{c}$ \\
W2LF1 & 1 & $49.56 \mathrm{bc}$ & $65.87 \mathrm{bc}$ & $19.46 \mathrm{ab}$ & $15.30 \mathrm{bcd}$ & $57.57 \mathrm{~b}$ & $74.27 \mathrm{bc}$ & $11.16 \mathrm{ab}$ \\
W2LF2 & 1 & $55.33 \mathrm{ab}$ & $75.37 \mathrm{ab}$ & $19.88 \mathrm{ab}$ & $14.24 \mathrm{cde}$ & $71.28 \mathrm{a}$ & $79.70 \mathrm{~b}$ & $21.53 \mathrm{bc}$ \\
W2LF3 & 1 & $71.22 \mathrm{a}$ & $92.21 \mathrm{a}$ & $22.71 \mathrm{a}$ & $18.17 \mathrm{a}$ & $73.24 \mathrm{a}$ & $113.33 \mathrm{a}$ & $40.49 \mathrm{a}$ \\
W3LF1 & 4.7 & $33.22 \mathrm{c}$ & $48.21 \mathrm{~cd}$ & $13.35 \mathrm{~cd}$ & $11.12 \mathrm{f}$ & $26.24 \mathrm{~d}$ & $54.03 \mathrm{~d}$ & $11.15 \mathrm{bc}$ \\
W3LF2 & 4.7 & $40.56 \mathrm{bc}$ & $64.87 \mathrm{bc}$ & $14.54 \mathrm{bcd}$ & $16.54 \mathrm{~b}$ & $39.91 \mathrm{c}$ & $57.70 \mathrm{~cd}$ & $21.16 \mathrm{bc}$ \\
W3LF3 & 4.7 & $51.22 \mathrm{~b}$ & $70.21 \mathrm{~b}$ & $16.32 \mathrm{bc}$ & $15.37 \mathrm{bc}$ & $45.24 \mathrm{c}$ & $73.00 \mathrm{bc}$ & $18.82 \mathrm{bc}$ \\
\hline
\end{tabular}

Note: The values followed by at least one same character are not statistically different at $5 \%$ probability level. $\mathrm{W}_{1}=$ varzaneh wastewater $(9 \mathrm{dS} / \mathrm{m}), \mathrm{W}_{2}=$ Isfahan university of technology's wastewater $(1 \mathrm{dS} / \mathrm{m}), \mathrm{W}_{3}=$ blended wastewater (blending of $\mathrm{W}_{1}$ and $\mathrm{W}_{2}$ wastewaters with 1:1 ratio, $4.7 \mathrm{dS} / \mathrm{m}$ ). $\mathrm{LF}_{1}=0 \%$ leaching fraction, $\mathrm{LF}_{2}=15 \%$ leaching fraction, $\mathrm{LF}_{3}=30 \%$ leaching fraction 
applied.

\section{Irrigation water use efficiency (IWUE)}

Irrigation water salinity significantly effected IWUE based on mean comparison results presented in Table 7. As irrigation water salinity increased, IWUE significantly decreased. The $\mathrm{W}_{3}$ wastewater (blending treatment) significantly increased IWUE in comparison with $\mathrm{W}_{1}$ wastewater. The 15 and 30 percent leaching caused 8 and 35 percent increase in IWUE, respectively, which only the 30 percent leaching effect was significant. It can be concluded that mixing wastewater and leaching can successfully improve the salinity condition. Results of treatments interaction effects (Table 8) show that irrigation with $\mathrm{W}_{3}$ wastewater without leaching application significantly increased IWUE of plant in comparison with $\mathrm{W}_{1}$ wastewater treatment with 0 and 15 percent leaching application. Interaction effects results also show that there was no significant difference between effects of irrigation with $\mathrm{W}_{3}$ wastewater with the 15 and 30 percent leaching application and irrigation with $\mathrm{W}_{2}(1 \mathrm{dS} / \mathrm{m})$ wastewater with 0 and 15 percent leaching application.

\section{Stem diameter}

As shown in Table 7, irrigation water salinity and leaching significantly affected plant stem diameter. Same as the other plant components, increase of irrigation water salinity significantly reduced corn stem diameter. $\mathrm{W}_{3}$ treatment increased stem diameter significantly in comparison with $\mathrm{W}_{1}$ treatment. Increasing leaching from 0 to 15 percent, significantly increased stem diameter. However, no significant difference between 15 and 30 percent leaching effects has been observed. Results of the treatments interaction effects (Table 8) show that increasing level of leaching from 15 to 30 percent reduced corn stem diameter for irrigation with saline wastewaters $\left(\mathrm{W}_{1}\right.$ and $\left.\mathrm{W}_{3}\right)$ but this effect was not statistically significant. In addition, interaction results show that application of the 15 and 30 percent leaching for irrigation with $\mathrm{W}_{1}$ and $\mathrm{W}_{3}$ wastewaters significantly increased plant stem diameter in comparison treatments, where no leaching was applied.

\section{Stem height}

As shown in the Table 7, irrigation water salinity and leaching fraction had significant impacts on stem height. Irrigation water salinity significantly reduced stem height and leaching significantly increased stem height. In addition, increase of stem height was observed for irrigation with $\mathrm{W}_{3}$ treatment in comparison with $\mathrm{W}_{1}$ treatment. Results of treatments interaction effects show that the application 15 and 30 percent leaching significantly increased corn stem height in comparison with treatments, which no leaching was applied. However, only for irrigation with $\mathrm{W}_{1}$ wastewater the 15 and 30 percent leaching effects was statistically significant in comparison with each other. In addition, interaction results show that there was no significant difference between effects of irrigation with $\mathrm{W}_{1}$ wastewater with the 30 percent leaching application and irrigation with $\mathrm{W}_{3}$ wastewater with 15 and 30 percent leaching application.

\section{Leaf area}

As shown in the Table 7, irrigation water salinity and leaching fraction had significant effects on corn leaf area which this result is consistent with the results of Mostafazadeh-Fard et al. (2009), Amer (2010) and Heakal et al. (1990). Same as the other plant components, increase of irrigation water salinity significantly reduced leaf area and increase of leaching significantly increased leaf area. In comparison with $\mathrm{W}_{1}$ treatment, $\mathrm{W}_{3}$ treatment significantly increased plant leaf area. The 15 and 30 percent leaching significantly increased leaf area about 23 and 66 percent, respectively. Therefore, it can be concluded that leaching can be a successful way to improve leaf area of forage corn plant. Results of interaction effects of the treatments (Table 8) show that the 15 percent leaching application significantly increased leaf area only for irrigation with saline-sodic wastewater $\left(\mathrm{W}_{1}\right)$. The 30 percent leaching application significantly increased leaf area for all of three wastewaters used in this experiment. Results of interaction effects also show that there was no difference between effects of the 30 percent leaching application for irrigation with $\mathrm{W}_{1}(9 \mathrm{dS} / \mathrm{m})$ wastewater and 15 percent leaching application for irrigation with $\mathrm{W}_{2}(1 \mathrm{dS} / \mathrm{m})$ wastewater.

\section{Root volume}

Root volume as an indicator of plant growth, should be evaluated. As shown in Table 7, irrigation water salinity and leaching significantly affected root volume. Same as the other plant components increase of irrigation water salinity reduced root volume and increase of leaching increased root volume. In comparison with $\mathrm{W}_{1}$ treatment, $\mathrm{W}_{3}$ treatment did not significantly affect corn root volume. The 15 and 30 percent leaching caused 21 and 57 percent increment in root volume respectively. Interaction effects of treatments results (Table 8), indicates that only the application of 30 percent leaching for irrigation with $\mathrm{W}_{3}$ wastewater significantly affected corn root volume in comparison with other experimental treatment.

\section{Conclusion}

The effects of different types of municipal wastewaters as irrigation water and leaching on soil chemical properties and corn yield were studied. Results showed that increasing 
of leaching fraction effectively reduced soil salinity but its effect on soil SAR was not statistically significant. Application of the 30 percent leaching fraction significantly reduced soil salinity accumulation at $0-10 \mathrm{~cm}$ depth only for irrigation with saline-sodic wastewater. The 15 and 30 percent leaching fraction significantly affected corn dry weight yield, stem diameter, stem height and leaf area but only the 30 percent leaching application significantly affected corn dry biomass and IWUE (Irrigation Water Use Efficiency). By blending of non-saline or non-sodic wastewater and saline-sodic wastewater with 1:1 ratio in order to use it for irrigation in combination with leaching application, high corn production can be achieved without significant difference in comparison with non-saline or nonsodic wastewater irrigation. The significance result of this study is production of corn plant even in condition that salinity and sodicity of irrigation water are beyond threshold value of plant. These results can be considered as a solution in areas which water scarcity is main problem of agricultural systems of the region. The results obtained in this study needed to be extrapolated by further field experiments to be realistic but the general trend of results of this study can be a clue for future investigation.

\section{Acknowledgment}

This study was financially supported by Isfahan University of Technology, which is appreciated. Special thanks to Prof. Afuyni and Prof. Haj Abbasi, faculty members of Soil Science Department at Isfahan University of Technology, for their great comments.

\section{References}

-Lal, K., P.S. Minhas and R.K. Yadav. 2015. Long-term impact of wastewater irrigation and nutrient rates II. Nutrient balance, nitrate leaching and soil properties under peri-urban cropping systems. Agricultural Water Management 156: 110-117.

Amer, K.H. 2010. Corn crop response under managing different irrigation and salinity levels. Agricultural Water Management 97: 1553-1563.

Anonymous. 2013. Corn production in Iran. Retrieved from http://www.indexmundi.com/

Arienzo, M., E.W. Christen, N.S. Jayawardane and W.C. Quayle. 2012. The relative effects of sodium and potassium on soil hydraulic conductivity and implications for winery wastewater management. Geoderma 173: 303-310.

Ayers, R.S. and D.W. Westcot. 1985. Water quality for agriculture. FAO Irrigation and drainage paper 29 Rev. 1. Food and Agricultural Organization. Rome.

Bame, I.B., J.C. Hughes, L.W. Titshall and C.A. Buckley. 2014. The effect of irrigation with anaerobic baffled reactor effluent on nutrient availability, soil properties and maize growth. Agricultural Water Management 134: 50-59.

Batziaka, V., K. Fytianos and E. Voudrias. 2008. Leaching of nitrogen, phosphorus, TOC and COD from the biosolids of the municipal wastewater treatment plant of Thessaloniki. Environmental Monitoring and Assessment 140: 331-338.

Bedbabis, S., B. Ben Rouina, M. Boukhris and G. Ferrara. 2014. Effect of irrigation with treated wastewater on soil chemical properties and infiltration rate. Journal of Environmental Management 133: 45-50.

Bedbabis, S., D. Trigui, C. Ben Ahmed, M.L. Clodoveo, S. Camposeo, G.A. Vivaldi and B. Ben Rouina. 2015. Long-terms effects of irrigation with treated municipal wastewater on soil, yield and olive oil quality. Agricultural Water Management 160: 14-21

Ben Ahmed, C., S. Magdich, B. Ben Rouina, M. Boukhris and F. Ben Abdullah, 2012. Saline water irrigation effects on soil salinity distribution and some physiological responses of field grown Chemlali olive. Journal of Environmental Management 113: 538-544.

Blum, J., A.J. Melfi, C.R. Montes and T.M. Gomes. 2013. Nitrogen and phosphorus leaching in a tropical Brazilian soil cropped with sugarcane and irrigated with treated sewage effluent. Agricultural Water Management 117: 115-122.

Chaganti, V.N. and D.M. Crohn. 2015. Evaluating the relative contribution of physiochemical and biological factors in ameliorating a saline-sodic soil amended with composts and biochar and leached with reclaimed water. Geoderma 259: 45-55.

Chaganti, V.N., D.M. Crohn and J. Šimůnek. 2015. Leaching and reclamation of a biochar and compost amended saline-sodic soil with moderate SAR reclaimed water. Agricultural Water Management 158: 255-265.

Chang, D. and Z. Ma. 2012. Wastewater reclamation and reuse in Beijing: Influence factors and policy implications. Desalination 297: 72-78.

Chen, W., S. Lu, W. Jiao, M. Wang and A.C. Chang. 2013. Reclaimed water: A safe irrigation water source? Environmental Development 8: 74-83.

Choudhary, O.P., B.S. Ghuman, A.S. Josan and M.S. Bajwa. 2006. Effect of alternating irrigation with sodic and nonsodic waters on soil properties and sunflower yield. Agricultural Water Management 85: 151-156.

Eck, H.V. 1984. Irrigated corns yield response to nitrogen and water. Agronomy Journal 76: 421-428.

Magesana, G.N., C. D.A. MacLay. and V.V. Lal. 1998. Nitrate leaching from a free-draining volcanic soil irrigated with municipal sewage efluent in New Zealand. Agriculture, Ecosystems and Environment 70: 181-187. 
Gengmao, Z., S.K. Mehta and L. Zhaopu. 2010. Use of saline aquaculture wastewater to irrigate salt-tolerant Jerusalem artichoke and sunflower in semiarid coastal zones of China. Agricultural Water Management 97: 1987-1993.

Estefan, G. and J.R. Rolf Sommer. 2013. Methods of Soil, Plant, and Water Analysis: A manual for the West Asia and North Africa region.

Grattan, S.R., S.E. Benes, D.W. Peters and F. Diaz. 2008. Feasibility of Irrigating Pickleweed (. Torr) with Hypersaline Drainage Water. Journal of Environment Quality 37: S-149.

Grattan, S.R., F.J. Díaz, F. Pedrero and G.A. Vivaldi. 2015. Assessing the suitability of saline wastewaters for irrigation of Citrus spp.: Emphasis on boron and specific-ion interactions. Agricultural Water Management 157: 48-58.

Grattan, S.R., J.D. Oster, S.R. Kaffka and M.C. Shannon, 2000. Reuse of Saline-Sodic Drainage Water for Irrigation. In Watershed Management and Operations Management p. 1-9.

Heakal, M.S., A.S. Modaihsh, A.S. Mashhady and A.I. Metwally. 1990. Combined effects of leaching fraction, salinity, and potassium content of waters on growth and water-use efficiency of wheat and barley. Plant and Soil 125: 177-184.

Heidarpour, M., B. Mostafazadeh-Fard, J. Abedi Koupai and R. Malekian. 2007. The effects of treated wastewater on soil chemical properties using subsurface and surface irrigation methods. Agricultural Water Management 90: 87-94.

Heidarpour, M., B. Mostafazadeh-Fard, A. Arzani, A. Aghakhani and M. Feizi. 2009. Effects of Irrigation Water Salinity and Leaching Fraction on Yield and Evapotranspiration in Spring Wheat. Communications in Soil Science and Plant Analysis 40: 2521-2535.

Jalali, M., H. Merikhpour, M.J. Kaledhonkar and S.E.A.T.M. Van Der Zee. 2008. Effects of wastewater irrigation on soil sodicity and nutrient leaching in calcareous soils. Agricultural Water Management 95: 143-153.

Kang, Y., M. Chen and S. Wan. 2010. Effects of drip irrigation with saline water on waxy maize (Zea mays L. var. ceratina Kulesh) in North China Plain. Agricultural Water Management 97: 1303-1309.

Katerji, N. 2003. Comparison of corn yield response to plant water stress caused by salinity and by drought. Agricultural Water Management 65: 95-101.

Keller, J., and R.D. Bliesner, 1990. Sprinkle and trickle irrigation. New York (USA) Van Nostrand Reinhold.

Kirkham, M.B.B. 2005. Principles of soil and plant water relations. $\quad$ Retrieved from http://books.google.com.br/books/about/Principles_of_S oil_and_Plant_Water_Relat.html?id=NUcoZNPMQEEC andpgis $=1$
Li, C., J. Lei, Y. Zhao, X. Xu and S. Li. 2015. Effect of saline water irrigation on soil development and plant growth in the Taklimakan Desert Highway shelterbelt. Soil and Tillage Research 146: 99-107.

Maas, E.V. and G.J. Hoffman. 1976. ICASALS, 1977. Crop salt tolerance [expressed as the decrease in yield]: evaluation of existing data. International Conference on Managing Saline Water for Irrigation, Planning for the Future. Lubbock. Tex. (USA).

Marchuk, A.G. and P. Rengasamy. 2010. Cation ratio of soil structural stability (CROSS). In 19th World Congress of Soil Science. pp. 5981-5983.

Marofi, S., M. Shakarami, G. Rahimi and F. Ershadfath. 2015. Effect of wastewater and compost on leaching nutrients of soil column under basil cultivation. Agricultural Water Management 158: 266-276.

Mohammad Rusan, M.J., S. Hinnawi and L. Rousan. 2007. Long term effect of wastewater irrigation of forage crops on soil and plant quality parameters. Desalination 215: 143-152.

Mostafazadeh-Fard, B., H. Mansouri, S.F. Mousavi and M. Feizi. 2009. Effects of different levels of irrigation water salinity and leaching on yield and yield components of wheat in an arid region. Journal of Irrigation and Drainage Engineering 135: 32-38.

Murtaza, G., A. Ghafoor, and M. Qadir. 2006. Irrigation and soil management strategies for using saline-sodic water in a cotton-wheat rotation. Agricultural Water Management. 81: 98-114.

Musick, J.T., A., and D.A. Duseek. 1980. Irrigation corn yield response to water. Transaction ASAE, 23: 92-98.

Oster, J. D., and S. R. Grattan. 2002. Drainage water reuse. Irrigation and Drainage Systems, 16: 297-310.

Page, A.L., A. Ayanaba, M.S. Baram, G.W. Barrett, W.G. Boggess, A. Chang. T.E. Long. 1996. Use of reclaimed water and sludge in food crop production. National Research Council.

Payero, J.O., D.D. Tarkalson, S. Irmak, D. Davison and J.L. Petersen. 2008. Effect of irrigation amounts applied with subsurface drip irrigation on corn evapotranspiration, yield, water use efficiency, and dry matter production in a semiarid climate. Agricultural Water Management 95: 895-908.

Qadir, M and J. Oster. 2004. Crop and irrigation management strategies for saline-sodic soils and waters aimed at environmentally sustainable agriculture. Science of The Total Environment 323: 1-19.

Qadir, M., A.S. Qureshi and S.A.M. Cheraghi. 2008. Extent and characterisation of salt-affected soils in Iran and strategies for their amelioration and management. Land Degradation and Development 19: 214-227. 
Seckler, D., R. Barker and U. Amarasinghe. 1999. Water Scarcity in the Twenty-first Century. International Journal of Water Resources Development 15: 29-42.

Shahabfar, A., A. Ghulam, and J. Eitzinger. 2012. Drought monitoring in Iran using the perpendicular drought indices. International Journal of Applied Earth Observation and Geoinformation 18: 119-127.

Shainberg, I. and J. Letey. 1984. Response of sodic soils to saline conditions. Hilgardia 52: 1-57.

Sou/Dakouré, M.Y., A. Mermoud, H. Yacouba and P. Boivin, 2013. Impacts of irrigation with industrial treated wastewater on soil properties. Geoderma 200: 31-39.

Steduto, P., J.M. Faurès, J. Hoogeveen, J. Winpenny. and J. Burke. 2012. Coping with water scarcity: an action framework for agriculture and food security. Food and Agriculture Organization of the United Nations Rome, Italy.
Wan, S., Y. Kang, D. Wang and S. Liu. 2010. Effect of saline water on cucumber (Cucumis sativus L.) yield and water use under drip irrigation in North China. Agricultural Water Management 98: 105-113.

Zhang, C.Y., S. Zhang, M.Y. Yin, L.N. Ma, Z. He, and Z. Ning. 2013. Nitrogen isotope studies of nitrate contamination of the thick vadose zones in the wastewater-irrigated area. Environmental Earth Sciences 68: $1475-1483$. 